\title{
PENGGUNAAN APD UNTUK PENCEGAHAN \\ PENYAKIT AKIBAT KERJA \\ PADA PERAWAT
}

\author{
Rahel Juliana Benedikta Berutu
}

E-mail : beruturahel1507@gmail.com

\section{LATAR BELAKANG}

Rumah sakit adalah sebuah industri jasa tempat penyediaan layanan kesehatan untuk masyarakat. Rumah sakit merupakan salah satu tempat kerja yang berpotensi menimbulkan bahaya. Karena berbahaya terkadang orang orang yang berada di rumah sakit bisa saja terkena penyakit, bukan hanya pengunjung namun orang orang yang bekerja di rumah sakit lebih cenderung terkena penyakit akibat kerja di rumah sakit.

Penyakit karena kerja bisa menyerang semua tenaga kerja di dalam rumah sakit, baik tenaga medis ataupun non medis karena pajanan biologi, kimia serta fisik di lingkungan kerja rumah sakit tersebut. Penyakit karena kerja adalah seuatu kendala pada tingkat keamanan dalam kerja, dalam perihal ini memerlukan usaha pencegahan, baik untuk keselamatan ataupun kesehatan beberapa pekerja yang berada di lingkungan rumah sakit. Penyakit karena kerja atau terkait dengan pekerjaan bisa dikarenakan oleh pemajanan di lingkungan kerja dengan terus menerus setiap hari.

Penyakit Akibat Kerja adalah setiap penyakit yang disebabkan oleh pekerjaan atas lingkungan kerja (Permennakertrans No. PER/01/MEN 1981 dalam Santoso, 2012). Penyakit yang disebabkan hubungan dengan faktor penyebab spesifik di tempat kerja yang sepenuhnya dapat dipastikan dan faktor tersebut dapat diidentifikasi diukur dan selanjutnya dapat dikendalikan (WHO, dalam Santoso, 2012).

Kemungkinan petugas rumah sakit pada gangguan kesehatan serta kecelakaan kerja biasanya dikarenakan oleh perilaku petugas dalam kepatuhan melakukan tiap-tiap mekanisme pada kewaspadaan. Lihat hal diatas tentu saja kita perlu mengerti jika dalam cakupan pekerjaan di bagian kesehatan memiliki banyak resiko pada kesehatan pekerja. Tenaga kerja (tenaga medis serta non medis) yang berefek pada penyakit karena kerja di dalam rumah sakit diantaranya Perawat yang setiap hari kontak dengan pasien dalam tempo yang lumayan lama 6 sampai 8 jam /hari, hingga tetap terpajan pada mikroorganisme pathogen bisa membawa infeksi dari satu pasien ke pasien yang lainnya. Hasil riset menunjukkan jika tenaga kerja perawat banyak diketemukan cedera sprain serta strain, nyeri pinggang, adalah keluhan paling banyak yang diketemukan pekerja perawat di dalam rumah sakit. Luka sayat serta tusukan jarum yang tidak sesuai mekanisme penggunaannya atau saat pencucian instrument tajam yang beresiko tersayat. Perilaku tidak aman perawat saat bekerja tanpa menggunakan alat pelindung diri sesuai standar dapat mengakibatkan kecelakaan kerja dan menimbulkan 
penyakit akibat kerja. Cedera akibat tusukan jarum pada perawat merupakan masalah yang signifikan dalam institusi pelayanan kesehatan dewasa ini. Ketika perawat tanpa sengaja menusuk dirinya sendiri dengan jarum suntik yang sebelumnya masuk ke dalam jaringan tubuh pasien, perawat beresiko terjangkit sekurang-kurangnya 20 patogen potensial.

Dalam hal ini, di perlukan perlindungan diri dari tenaga kesehatan sendiri, seperti perawat yang bertemu dan bertatap muka dengan pasien 24 jam setiap harinya. Salah satu upaya pencegahan penyakit akibat kerja yang dapat di lakukan oleh perawat adalah menggunakan APD (Alat Pelindung Diri).

Kata kunci : Alat pelindung diri, penyakit akibat kerja, perawat

\section{METODE}

Metode penulisan yang digunakan dalam penulisan laporan ini adalah literature review. Literature review yang dilakukan berupa telaah pustaka artikel penelitian. Artikel dipublikasikan secara elektronik dan diunduh melalui Google Scholar,science direct, scopus, ebook, dan dari beberapa buku keperawatan.. Kata Kunci yang digunakan yaitu Alat Pelindung Diri (APD), Penyakit akibat kerja, serta Perawat. Kriteria inklusi artikel adalah diterbitkan dari tahun 2012 hingga 2020, dan fulltext. Prosedur pengumpulan data yang digunakan adalah menentukan keyword untuk pencarian literatur yang relevan dengan topik kajian dan melakukan penelusuran mengenai topik relevan.

\section{HASIL}

Jurnal yang berjudul HUBUNGAN ANTARA PENGAWASAN, PROSEDUR KERJA DAN KONDISI FISIK DENGAN TERJADINYA KECELAKAAN KERJA PADA PERAWAT DI RUANG RAWAT INAP RUMAH SAKITPERMATA BUNDA MEDAN bertujuan untuk Meningkatkan kesadaran Rumah sakit untuk melakukan pelatihan keselamatan dan kesehatan kerja kepada perawat terkhusunya mengenai penggunaan APD dan ergonomi, Perawat diharapkan untuk meningkatkan kesadaran diri untuk dapat berperilaku aman seperti mengikuti prosedur kerja yang ditetapkan, menggunakan APD, dan melaporkan setiap kecelakaan kerja untuk selanjutnya dapat dievaluasi agar kejadian kecelakaan kerja tidak terulang kembali, Kepala perawat diharapkan sebagai pelaksana aktif dalam mengawasi perawat dengan cara melakukan pengarahan setiap terjadi pergantaian jam kerja, mengingatkan perawat jika mereka melakukan kesalahan, memotivasi perawat untuk bertindak aman dan menciptakan lingkungan kerja yang aman dan nyaman sehingga dpata meningkatkan derajat kesehatan perawat.

Jurnal yang berjudul KEJADIAN KECELAKAAN KERJA PERAWAT BERDASARKAN TINDAKAN TIDAK AMAN bertujuan untuk memberi informasi kepada pembaca bahwa Tindakan tidak aman (unsafe action) adalah tindakan yang dapat membahayakan pekerja itu sendiri maupun orang lain yang dapat menyebabkan terjadinya kecelakaan yang dapat disebabkan oleh berbagai hal seperti tidak memakai APD, tidak mengikuti prosedur kerja, tidak mengikuti peraturan keselamatan kerja dan bekerja tidak hatihati, dimana dari setiap 300 tindakan tidak aman, akan terjadi 1 (satu) kali kecelakaan yang mengakibatkan kehilangan hari kerja. Ancaman kecelakaan kerja di tempat kerja di negara berkembang seperti Indonesia masih sangat tinggi oleh sebab itu di perlukan penggunaan 
APD yang lebih ketat lagi oleh perawat di Rumah Sakit, terutama perawat yang bekerja di ruangan khusus penderita penyakit menular.

Jurnal yang berjudul PENYAKIT AKIBAT KERJA DAN PENCEGAHAN bertujuan untuk memberi informasi kepada pembaca untuk menghindari penyakit akibat kerja pada perawat di perlukan Perlindungan khusus (specific protection). Misalnya: imunisasi, hygiene perorangan, sanitasi lingkungan, serta proteksi terhadap bahaya dan kecelakaan kerja dengan menggunakan alat pelindung diri (APD) seperti helm, kacamata kerja, masker, penutup telinga (ear muff dan ear plug) baju tahan panas, sarung tangan, dan sebagainya. Serta menginformasikan upaya yang dapat dilakukan oleh perusahaan untuk mencegah PAK yaitu dengan menyingkirkan atau mengurangi risiko pada sumbernya, misalnya menggantikan bahan kimia yang berbahaya dengan bahan yang tidak berbahaya, mengurangi risiko dengan pengaturan mesin atau menggunakan APD, menetapkan prosedur kerja secara aman untuk mengurangi risiko lebih lanjut serta menyediakan, memakai dan merawat APD.

Jurnal yang berjudul Perilaku Pencegahan Penyakit Akibat Kerja Tenaga Kerja Indonesia di Kansashi, Zambia: Analisis Kualitatif bertujuan untuk menginfotmasikan kepada pembaca untuk memperbaiki kondisi saat ini adalah adanya peningkatan peran serta para pekerja dalam pencegahan PAK; Penyampaian informasi tentang PAK serta pencegahannya yang dilakukan secara rutin di perusahaan atau di lapangan tempat kerja termasuk menanamkan pemahaman konsep hidup sehat kepada para pekerja; Menciptakan lingkungan kerja yang mendukung pencegahan PAK; Update kebijakan perusahaan yang terus menerus supaya para pekerja tahu, mengerti, serta dapat mengikuti dan patuh terhadap kebijakan perusahaan terutama berkaitan dengan pencegahan PAK; Adanya SOP PAK yang jelas serta sanksi yang tegas bagi yang melanggarnya; Melengkapi fasilitas pelayanan kesehatan yang lebih baik beserta keterampilan dan keramahan petugas kesehatan/medis; Melaksanakan pelatihan terhadap pimpinan agar tidak fokus hanya target perusahaan tetapi juga mempunyai perhatian terhadap pencegahan PAK.

Jurnal yang berjudul PERILAKU PERAWAT DALAM PENGGUNAAN ALAT PELINDUNG DIRI (APD) DI IRNA MEDIKAL RSUD PEKANBARU bertujuan untuk menginformasikan bahwa pelaksanaan APD itu sendiri merupakan hal wajib yang harus dilakukan perawat, guna mencegah terjadinya kecelakaan kerja maupun mencegah pasien tertular penyakit dari satu pasien lainnya, yang mana dapat meningkatkan massa rawat pasien tersebut. Saling keterkaitan ini harus lebih diperhatikan lagi bagi para pembuat kebijakan, keselamatan masyarakat yang dikedepankan, tak terlepas dari keselamatan tenaga medis itu sendiri. Diharapkan memberikan sarana pada mahasiswa/I praktik, sehingga dapat membantu terwujudnya kesehatan, keselamatan baik bagi tenaga kesehatan maupun pasien. Diharapkan dapat melakukan penelitian yang lebih lanjut mengenai faktor-faktor yang mempengaruhi pelaknaan APD di instansti pemerintahan, sehingga tidak hanya mengevaluasi pihak bawah (tenaga kesehatan) yang langsung berinteraksi dengan masyarakat dalam hal ini pasien, tetapi juga pihak atas pembuat kebijakan itu sendiri.

\section{PEMBAHASAN}

Perawat merupakan sumber daya manusia di rumah sakit yang memberikan pelayanan kepada pasien.Universal precaution merupakan pencegahan penularan penyakit dari tenaga 
kesehatan dan sebaliknya. Perawat merupakan petugas kesehatan terbanyak dengan komposisi hampir $60 \%$ dari seluruh petugas kesehatan di rumah sakit dan salah satu profesi yang sering terkena penyakit akibat kerja karena perawat tenaga kesehatan yang 24 jam berada di samping dan bersentuhan dengan pasien. Kontaminasi penyakit dapat berisiko terjadi pada seorang perawat maupun dokter apabila selama melakukan interaksi dengan pasien tidak memperhatikan tindakan pencegahan (universal precaution) dengan cara menggunakan alat pelindung diri (APD)seperti sarung tangan, masker, kaca mata. Alat Pelindung Diri (APD) sangat penting untuk dipakai oleh seorang perawat dalam melaksanakan tugas, alat pelindung diri digunakan oleh petugas memiliki dua fungsi yaitu untuk kepentingan perawat dan sekaligus untuk kepentingan petugas itu sendiri.

Alat pelindung diri terbukti mampu membantu perawat memperlancar pelayanan kesehatan oleh karena itu pengetahuan tentang alat pelindung diri dasar harus dikuasi penuh oleh perawat agar tingkat kepuasan pasien semakin baik. Perlunya peningkatan pengawasan terhadap perawat dalam penggunaan APD saat melakukan tindakan keperawatan.Pelaksanaan APD itu sendiri merupakan hal wajib yang harus dilakukan perawat, guna mencegah terjadinya kecelakaan kerja maupun mencegah pasien tertular penyakit dari satu pasien lainnya, yang mana dapat meningkatkan massa rawat pasien tersebut. Saling keterkaitan ini harus lebih diperhatikan lagi bagi para pembuat kebijakan, keselamatan masyarakat yang dikedepankan, tak terlepas dari keselamatan tenaga medis itu sendiri. Kepatuhan dalam penggunaan APD di rumah sakit dipengaruhi oleh komunikasi, keterbatasan alat, pengawasan, dan sikap dari perawat itu sendiri.Kontaminasi penyakit yang terjadi di lingkungan rumah sakit dapat dicegah dengan meningkatkan keamanan dan kedisiplinan perawat dalam menggunakan alat pelindung diri dan itu berlaku bagi semua perawat yang ada di seluruh unit pelayanan. Penggunaan Alat Pelindung Diri (APD) termasuk faktor lingkungan karena APD merupakan salah satu alat untuk melidungi diri para pekerja guna mengurangi resiko kecelakaan kerja. Jadi, kepatuhan dalam penggunaan alat pelindung diri merupakan perilaku keselamatan spesifik terhadap objek lingkungan kerja. Kepatuhan penggunaan alat pelindung diri memiliki peran yang penting dalam menciptakan keselamatan di tempat kerja. Berbagai contoh perilaku (tindakan) kurang aman yang sering ditemukan di tempat kerja pada dasarnya adalah perilaku tidak patuh terhadap prosedur kerja/operasi, seperti menjalankan mesin atau peralatan tanpa wewenang, mengabaikan peringatan dan keamanan, kesalahan kecepatan pada saat mengoprasikan mesin/ peralatan, tidak menggunakan alat pelindung diri dan memperbaiki peralatan yang sedang bergerak atau dalam keadaan hidup atau dengan kata lain tidak mengikuti prosedur kerja yang benar.

Alat Pelindung Diri (APD) perlu sebelumnya dipilih secara hati-hati agar dapat memenuhi beberapa ketentuan yang diperlukan, yaitu Alat Pelindung Diri (APD) harus dapat memberikan perlindungan yang adekuat terhadap bahaya yang spesifik atau bahayabahaya yang dihadapi oleh tenaga kerja, berat alatnya hendaknya seringan mungkin, dan alat tersebut tidak menyebabkan rasa ketidaknyamanan yang berlebihan, alat harus dapat dipakai secara fleksibel, bentuknya harus cukup menarik, alat pelindung tahan untuk pemakaian yang lama, alat tidak menimbulkan bahaya-bahaya tambahan bagi pemakainya, yang dikarenakan bentuknya yang tidak tepat atau karena salah dalam penggunaanya, alat pelindung harus memenuhi standar yang telah ada, alat tersebut tidak membatasi gerakan dan presepsi sensoris pemakainya dan suku cadangnya mudah didapat guna mempermudah pemeliharaannya.

Macam-macam Alat Pelindung Diri (APD). Alat Pelindung Diri (APD) ada berbagai macam yang berguna untuk melindungi seseorang dalam melakukan pekerjaan yang fungsinya untuk mengisolasi tubuh tenaga kerja dari potensi bahaya di tempat kerja. 
Berdasarkan fungsinya, ada beberapa macam APD yang digunakan oleh tenaga kerja di rumah sakit, antara lain :

1.Baju Pelindung (Body Potrection). Baju pelindung digunakan untuk melindungi seluruh atau sebagian tubuh dari percikan api, suhu panas atau dingin, cairan bahan kimia, dll. Contoh : Apron, merupakan pelindung pakaian yang terbuat dari bahan timbal yang dapat menyerap radiasi pengion. 2. Sepatu steril. Sepatu khusus yang digunakan oleh petugas yang bekerja di ruang bedah, laboratorium, ICU, ruang isolasi, ruang otopsi.

3. Alat Pelindung Tangan (Hand Protection). Alat pelindung tangan digunakan untuk melindungi tangan dan bagian lainnya dari benda tajam atau goresan, bahan kimia, benda panas dan dingin, kontak dengan arus listrik. Jenis alat pelindung tangan antara lain: sarung tangan bersih, sarung tangan bersih adalah sarung tangan yang di disinfeksi tingkat tinggi, dan digunakan sebelum tindakan rutin pada kulit dan selaput lendir misalnya tindakan medik pemeriksaan dalam, merawat luka terbuka. Sarung tangan bersih dapat digunakan untuk tindakan bedah bila tidak ada sarung tangan steril. Dan ada juga arung tangan steril, sarung tangan steril adalah sarung tangan yang disterilkan dan harus digunakan pada tindakan bedah. Bila tidak tersedia sarung tangan steril baru dapat digunakan sarung tangan yang didisinfeksi tingkat tinggi.

Saat melakukan prosedur pemakaian alat pelindung diri (APD), perlu ada seorang petugas terlatih yang melakukan supervisi prosedur sesuai protokol dan juga seorang asisten yang membantu memakaikan atribut tertentu. Berikut ini prosedur penggunaan (donning) APD:

1. Sebelum menggunakan alat pelindung diri, petugas melepaskan seluruh perhiasan yang dikenakan termasuk jam tangan. Petugas yang berambut panjang harus mengikat rambut. Petugas yang berkacamata harus melekatkan kacamata supaya tidak jatuh

2. Inspeksi kondisi alat pelindung diri, memastikan ukurannya sesuai dengan tubuh petugas dan tidak ada kerusakan pada alat

3. Lakukan cuci tangan (hand hygiene)

4. Kenakan sepatu Lalu, pasang boot cover, ikat tali yang melingkari boot cover. Usahakan tangan tidak menyentuh lantai. Tahap ini sebaiknya dikerjakan dalam posisi duduk

5. Kenakan sarung tangan (dalam)

6. Kenakan baju pelindung dan buat agar lengan baju menutupi pergelangan sarung tangan dalam. Pastikan semua bagian lengan sarung tangan masuk di bawah lengan baju pelindung. Pakaikan plester di pergelangan tangan apabila masih ada celah antara baju dengan sarung tangan

7. Kenakan masker N95. Pastikan seluruh bagian tepi menyesuaikan bentuk wajah sehingga tidak ada celah.

8. Kenakan hood, pastikan bagian telinga dan leher tertutup dan tidak ada rambut yang keluar. Bagian bawah hood harus menutupi kedua bahu. Asisten dapat membantu proses pemakaian

9. Kenakan apron (tidak wajib) apabila menangani pasien dengan gejala muntah dan diare 
10. Kenakan sarung tangan luar yang biasanya memiliki pergelangan lebih panjang. Tarik bagian lengan sarung tangan hingga menutupi bagian lengan baju pelindung. Penggunaan sarung tangan yang berbeda warna dengan sarung tangan dalam dapat membantu identifikasi

11. Kenakan pelindung wajah (face shield)

12. Evaluasi kelengkapan dan kesesuaian penggunaan alat pelindung diri menggunakan bantuan cermin, ditambah dengan verifikasi oleh petugas donning.

Berdasarkan pedoman $\mathrm{WHO}$, prosedur melepaskan alat pelindung diri sesuai urutan adalah sebagai berikut:

1. Lakukan cuci tangan (hand hygiene) dengan tetap menggunakan sarung tangan

2. Robek apron di bagian leher kemudian gulung ke bagian depan dan bawah. Hindari tangan menyentuh bagian coverall di belakang

3. Lakukan cuci tangan. Cuci tangan dilakukan setiap selesai melepaskan 1 jenis atribut alat pelindung diri

4. Lepaskan pelindung kepala-leher (bila hood terpisah dari baju pelindung) dengan cara menarik bagian atas penutup kepala. Bila menggunakan coverall kepala-mata kaki, buka terlebih dahulu resleting di bagian dada, kemudian lepaskan hoodie ke arah belakang secara perlahan dengan cara menggulung bagian dalam menjadi bagian luar. Hindari menyentuh bagian luar coverall

5. Setelah coverall terlepas melewati bahu hingga pertengahan siku, tarik lengan perlahan agar coverall terlepas bersama dengan sarung tangan luar. Teruskan membuka dan menggulung coverall dengan tetap menggunakan sarung tangan dalam, hingga terlepas seluruhnya dari bagian kaki

6. Lakukan cuci tangan kembali (terus dilakukan setiap selesai melepaskan 1 jenis atribut)

7. Lepaskan pelindung mata dengan memegang tali di bagian belakang

8. Lepaskan masker dengan menarik bagian tali bawah di belakang melewati kepala ke bagian depan. Dilanjutkan dengan melepaskan tali bagian atas

9. Lepaskan boot cover. Lalu, lepaskan sepatu boot tanpa menyentuh dengan tangan

10. Lepaskan sarung tangan dalam

11. Lakukan cuci tangan di akhir prosedu

Supaya tenaga kerja di lingkungan rumah sakit masih efektif serta produktif dalam melakukan pekerjaan serta tanggung jawabnya dan tidak mengalami penyakit karena kerja jadi tindakan untuk menghadapi hal itu memerlukan penerapan manajemen kesehatan serta keselamatan kerja di dalam rumah sakit. Manajemen kesehatan serta keselamatan kerja rumah sakit menyertakan semua unsur manajemen, karyawan serta lingkungan kerja yang terintegrasi menjadi usaha pencegahan serta kurangi kecelakaan kerja serta penyakit karena kerja di lingkungan rumah sakit yang mempunyai tujuan ialah membuat tempat kerja yang aman, sehat dan bebas dari pencemaran paparan lingkungan kerja, yang selanjutnya bisa meningkatkan efesiensi serta produktifitas kerja. 
Langkah awal yang peting ialah usaha pengendalian di lingkungan kerja rumah sakit diantaranya kesehatan kerja buat karyawan, sanitasi lingkungan rumah sakit, pengamanan pasien, pengunjung ataupun petugas rumah sakit dan sebagainya. Upaya-upaya yang bisa dikerjakan untuk kurangi serta mnghindarkan kecelakaan kerja serta penyakit karena kerja ialah seperti berikut:

1. Lakukan substitusi pengenalan lingkungan kerja lewat cara lihat serta menganal potensial bahaya lingkungan kerja. Mengganti perlengkapan kerja yang tidak wajar gunakan.

2. Pelajari lingkungan kerja dalam perihal ini menilai karakter serta besarnya potensipotensi bahaya yang mungkin muncul hingga dengan mudah bisa mengutamakan dalam menangani permasalahan yang lebih potensial.

3. Pengendalian lingkungan kerja dengan bertindak mengurangi bahkan juga menghilangkan pajanan pada masalah kesehatan pekerja dilingkungan kerja lewat cara teknologi pengendalian.

4. Pengendalian administratif dengan memperingatkan pekerja agar bisa memakai alat pelindung diri yang benar dan baik, membuat rambu-rambu bahaya dilingkungan kerja yang punya potensi bahaya.

5. Kontrol kesehatan pekerja dengan berkala untuk mencari aspek pemicu serta upaya penyembuhan.

6. Pendidikan serta penyuluhan kesehatan serta keselamatan kerja buat pekerja di lingkungan rumah sakit.

7. Pengendalian fisik lingkungan kerja, mengidentifikasi suhu, kelembapan, pencahayaan, getaran, kebisingan, pengendalian sistem ventilasi dan sebagainya.

8. Lakukan pengawasan serta monitoring dengan berkala pada lingkungan kerja rumah sakit.

9. Substitusi berbahan kimia, alat kerja serta mekanisme kerja.

Berikut ini adalah penerapan konsep lima tingkatan pencegahan penyakit (five level of prevention disease) pada penyakit akibat kerja, yakni:

a. Peningkatan kesehatan (health promotion). Misalnya: penyuluhan kesehatan dan keselamatan kerja (K3) pendidikan kesehatan, meningkatkan gizi yang baik, pengembangan kepribadian, perusahaan yang sehat dan memadai, rekreasi, lingkungan kerja yang memadai, penyuluhan perkawinan dan pendidikan seksual, konsultasi tentang keturunan dan pemeriksaan kesehatan periodik.

b. Perlindungan khusus (specific protection). Misalnya: imunisasi, hygiene perorangan, sanitasi lingkungan, serta proteksi terhadap bahaya dan kecelakaan kerja dengan menggunakan alat pelindung diri (APD) seperti helm, kacamata kerja, masker, penutup telinga (ear muff dan ear plug) baju tahan panas, sarung tangan, dan sebagainya.

c. Diagnosis (deteksi) dini dan pengobatan segera serta pembatasan titik-titik lemah untuk mencegah terjadinya komplikasi.

d. Membatasi kemungkinan cacat (disability limitation). Misalnya: memeriksa dan mengobati tenaga kerja secara komprehensif, mengobati tenaga kerja secara sempurna dan pendidikan kesehatan.

e. Pemulihan kesehatan (rehabilitation). Misalnya: rehabilitasi dan mempekerjakan kemali para pekerja yang menderita cacat. Sedapat mungkin perusahaan mencoba menempatkan 
keryawan-karyawan cacat di jabatan yang sesuai. Upaya yang dapat dilakukan oleh perusahaan untuk mencegah PAK adalah sebagai berikut:

1. Menyingkirkan atau mengurangi risiko pada sumbernya, misalnya menggantikan bahan kimia yang berbahaya dengan bahan yang tidak berbahaya.

2. Mengurangi risiko dengan pengaturan mesin atau menggunakan APD.

3. Menetapkan prosedur kerja secara aman untuk mengurangi risiko lebih lanjut.

4. Menyediakan, memakai dan merawat APD

Selain dengan menggunakan Alat Pelindung Diri (APD), Rumah sakit juga Disarankan agar pihak manajemen Rumah Sakit dapat meningkatkan upaya pengawasan, karena berdasarkan hasil penelitian pengawasan penggunaan safety shoes dan pengawasan posisi kerja perawat masih kurang diperhatikan. Oleh katena itu diharapakan Rumah Sakit Permata Bunda dapat melakukan pelatihan keselamatan dan kesehatan kerja kepada perawat terkhusunya mengenai penggunaan APD dan ergonomi dan Pihak manajemen rumah sakit juga harus dapat meningkatkan fasilitas beristirahat yang baik bagi para perawat guna mencegah terjadinya kelelahan serta menghilangkan rasa lelah perawat sehabis bekerja, membuat instrumen safe/unsafe action khusus perawat, Mengadakan refreshing SOP baru tiap 3 bulan, training/ pelatihan bagi karyawan baru maupun karyawan lama sehingga dapat meningkatkan kesadaran masing- masing individu untuk melatih budaya kerja secara aman (safe act culture), Membuat kebijakan terkait advokasi status kesejahteraan perawat dengan memberikan jaminan kesehatan yang baik melalui pemeriksaan kesehatan pra pekerja, berkala (baik yang sudah terpapar/beresiko ataupun tidak) dan pemeriksaan khusus (termasuk pemeriksaan sebelum pensiun) untuk mengetahui adanya Penyakit Akibat Kerja (PAK) serta penatalaksanaannya dan pemberian Vaksinasi sebagai tindakan pencegahan, perawat agar tetap berupaya meminimalkan faktor-faktor pemungkin dan membekali dirinya dengan meningkatkan pengetahuan melalui seminar, media internet atau buku guna mendapatkan informasi terbaru tentang K3 sehingga dalam menerapkan asuhan keperawatan selalu memperhatikan budaya kerja K3 secara aman dengan penekanan pada universal precautions, peneliti selanjutnya Menentukan periode waktu penelitian, menggunakan desain comparative dengan metode pengumpulan data: observasi

\section{PENUTUP}

\section{Kesimpulan}

Perawat adalah tenaga kesehatan yang paling besar jumlahnya dan paling lama kontak dengan pasien, sehingga sangat berisiko dengan pekerjaannya, namun banyak perawat tidak menyadari terhadap risiko yang mengancam dirinya, melupakan keselamatan dan kesehatan kerja (K3). Pelaksanaan APD itu sendiri merupakan hal wajib yang harus dilakukan perawat, guna mencegah terjadinya kecelakaan kerja maupun mencegah pasien tertular penyakit dari satu pasien lainnya, yang mana dapat meningkatkan massa rawat pasien tersebut. Saling keterkaitan ini harus lebih diperhatikan lagi bagi para pembuat kebijakan, keselamatan masyarakat yang dikedepankan, tak terlepas dari keselamatan tenaga medis itu sendiri. Alat pelindung diri terbukti mampu membantu perawat memperlancar pelayanan kesehatan oleh karena itu pengetahuan tentang alat pelindung diri dasar harus dikuasi penuh oleh perawat 
agar tingkat kepuasan pasien semakin baik. Perlunya peningkatan pengawasan terhadap perawat dalam penggunaan APD saat melakukan tindakan keperawatan.

\section{Saran}

Bagi perawat agar tetap berupaya meminimalkan faktor-faktor pemungkin dan membekali dirinya dengan meningkatkan pengetahuan melalui seminar, media internet atau buku guna mendapatkan informasi terbaru tentang K3 sehingga dalam menerapkan asuhan keperawatan selalu menggunakan alat pelindung diri (APD). Perawat diharapkan untuk meningkatkan kesadaran diri untuk dapat berperilaku aman seperti mengikuti prosedur kerja yang ditetapkan, menggunakan APD, dan melaporkan setiap kecelakaan kerja untuk selanjutnya dapat dievaluasi agar kejadian kecelakaan kerja tidak terulang kembali.

\section{DAFTAR PUSTAKA}

Apriluana, Gladys and Khairiyati, Laily and Setyaningrum, Ratna (2016) Hubungan Antara Usia, Jenis Kelamin, Lama Kerja, Pengetahuan, Sikap dan Ketersediaan Alat Pelindung Diri (APD) dengan Perilaku Penggunaan APD pada Tenaga Kesehatan. Jurnal Publikasi Kesehatan Masyarakat Indonesia (JPKMI) , 3 (3). pp. 82-87. ISSN 2407-1625

Azizah, N., Setiawan.,Silaban,G.(2017). HUBUNGAN ANTARA PENGAWASAN, PROSEDUR KERJA DAN KONDISI FISIK DENGAN TERJADINYA KECELAKAAN KERJA PADA PERAWAT DI RUANG RAWAT INAP RUMAH SAKITPERMATA BUNDA MEDAN. Jurnal JUMANTIK Vol. 3 No.2 Desember 2018 - Mei 2019

Hasugian, A., R. (2016). Perilaku Pencegahan Penyakit Akibat Kerja Tenaga Kerja Indonesia di Kansashi, Zambia: Analisis Kualitatif. Media Litbangkes, Vol. 27 No. 2, Juni 2017, 111124. http://dx.doi.org/10.22435/mpk.v27i2.5805.111-124

Maria, S., Wiyono, J., Candrawati, E. (2015). KEJADIAN KECELAKAAN KERJA PERAWAT BERDASARKAN TINDAKAN TIDAK AMAN. Jurnal Care Vol. 3, No. 2

Muchlis, S., Yusuf, M. (2016). KESADARAN PERAWAT DALAM PENGGUNAAN ALAT PELINDUNG DIRI (APD) NURSE' ON THE IMPORTANCE OF SELF PROTECTION DEVICE. Jurnal Ilmu Keperawatan Fakultas Keperawatan Universitas Syiah Kuala

Ramdan, I., M., Rahman, A. (2017). Analisis Risiko Kesehatan dan Keselamatan Kerja (K3) pada Perawat. Jurnal Keperawatan padjadjaran Vol 5, No 3 (2017) DOI: https://doi.org/10.24198/jkp.v5i3.645 pdf : https://doi.org/10.24198/jkp.v5i3.645.g169

Rejeki.(2012). Upaya Keselamatan Kerja Tentang APD. Jakarta. Rineka Cipta 
Salawati, L. (2015). PENYAKIT AKIBAT KERJA DAN PENCEGAHAN. JURNAL KEDOKTERAN SYIAH KUALA Volume 15 Nomor 2 Agustus 2015

Simamora, R. H. (2011). ROLE CONFLICT OF NURSE RELATIONSHIP WITH PERFORMANCE IN THE EMERGENCY UNIT OF HOSPITALS RSD DR. SOEBANDI JEMBER. The Malaysian Journal of Nursing, 3(2), 23-32.

Simamora, R. H. (2020). Pelatihan Komunikasi Efektif untuk Meningkatkan Efikasi diri Perawat dalam Pelaksanaan Identifikasi Pasien. JURNAL ILMIAH KESEHATAN MASYARAKAT: Media Komunikasi Komunitas Kesehatan Masyarakat, 12(1), 49-54.

Tukatman., Sulistiawati., Purwaningsih., Nursalam. (2015). ANALISIS KESELAMATAN DAN KESEHATAN KERJA PERAWAT DALAM PENANGANAN PASIEN DI RUMAH SAKIT BENYAMIN GULUH KABUPATEN KOLAKA. Jurnal Ners Vol. 10 No. 2 Oktober 2015: $343-347$

Wulandini, P., Roza, A. (2016). PERILAKU PERAWAT DALAM PENGGUNAAN ALAT PELINDUNG DIRI (APD) DI IRNA MEDIKAL RSUD PEKANBARU. Jurnal Keperawatan Universitas Abdurrab.Pekan Baru 